\title{
AN INTERACTIVE MAP OF THE MAIN BUS STATION IN LUBLIN - TRAVEL INFORMATION SYSTEM BASED ON GEOSPATIAL DATA SOURCES
}

\author{
Klaudia Mazur, Michał Maciąg, Patrycja Pochwatka
}

\begin{abstract}
Summary
The work aimed to create and share for public use an Interactive Map of the Main Bus Station in Lublin, using the base map as a primary data source. This solution may be an alternative to the most popular way of basing on the Google Maps or OpenStreetMap data. The final visualization was prepared by connecting digital geospatial data processing methods with land surveying techniques. The map was designed as an information system for travellers and other people moving through the bus station facility. The intended 'interactivity' includes the ability to display proper information about selected objects and choosing preferred viewing parameters, such as the scale or the type of base layer. The final product is an Internet application, created and published using the ArcGIS Online service, in contrast with the majority of similar applications, which are typically developed using Google Maps tools.
\end{abstract}

\section{Keywords}

interactive map • base map • GIS • travel information $\bullet$ Lublin

\section{Introduction}

A common disadvantage of travelling from transportation hubs, including bus stations, is the necessity of moving through a crowded area under time pressure. A vital problem for travellers may come from insufficient information about the situation of needed objects, such as for instance restrooms, shops or restaurants. The efficiency of bus station facilities such as information offices or information boards depends on the current location of each person and the view area, limited by other people and vehicles. A practical solution may be creating an Internet-based mobile information system, accessible using smartphones or other devices with touch screens.

In the present work, we aimed to create an Interactive Map of the Main Bus Station in Lublin, using several geospatial data sources. The product is a result of combining cartographic visualization with sharing the spatial data, complemented with the information about available bus connections. The final effect is a multifunctional web 
application, including a situation map showing bus platforms, nearby public transport, and other useful facilities. The supplementary content of the map is the information about the bus routes, nearby restaurant and other facilities, and links to potentially useful websites. The interactivity enables the user to choose the content of the map depending on current needs. In the design process, we collaborated with the management of the bus station - Lubelskie Dworce SA company - to obtain current databases, acquire necessary permissions, and distribute the product.

\section{An interactive map against contemporary trends}

The beginning of the $21^{\text {st }}$ century has brought remarkably dynamic expansion of Internet maps development technologies [Król and Prus 2016]. The term 'Internet maps' contains different kinds of solutions - from digital versions of traditional maps to extended multi-purpose online services of spatial information. There are more and more innovative products appearing in the virtual dimension, and the experts forecast their farther accelerated evolution [Gaździcki 2012]. Thanks to up-to-date technologies, access to spatial data is becoming more common, also amongst average users [Gagliardi et al. 2017].

Arising geoinformation services with various thematic data are usually designed as a combination of database elements, and geospatial visualization understood as a display of geographic information on a map [Król and Prus 2017, Gaździcki 2012, Pochwatka et al. 2017]. One of the modern forms of sharing spatial information is an interactive map, being a more efficient alternative to traditional maps. The 'interactivity' in connection with cartography mainly means the ability of the user to determine the range and form of presented data [Macioch and Malmon 2010]. That solution makes it possible, inter alia, to adjust parameters and content of the map to the current user needs, and to combine large quantity of information in one complex product [Smith 2016]. However, obtaining such results relies on cartographic knowledge and geoinformatics skills, including operating specialist software [Aletà et al. 2017].

The complexity of interactive maps designing process is differential, and it depends mainly on the technological sophistication of the target result. In some cases, these activities are diminished to combining and publishing several data files, however, usually creating a complete spatial visualization must be preceded by working on collecting and modifying the information [Król and Prus 2017].

\section{The characteristics of researched area}

The Main Bus Station in Lublin has been operating in its current location since 1967. The object is situated in the centre of the city, on Aleja Tysiąclecia (Millennium Avenue) - one of the largest and busiest streets of Lublin. The area of the bus station is neighbouring the historical buildings of Podzamcze district. On the other side of the avenue, there are Lublin Castle and The Old Town - the oldest existing part of the city. In the past, the area was a Jewish district, transformed into a ghetto during World War II. In 
1942 the residents were displaced, and the buildings gradually fell into disrepair. After the war, ruins of the former district were turned into Aleja Tysiąclecia, Plac Zamkowy (The Castle Square) and the Main Bus Station in Lublin [Kuwałek 2003].

The placement of the facility in accordance with the city topography and its main function mean that crowds of people visit the bus station daily. The buses that stop at this station are the means of transport for lots of those studying and working in Lublin - a leading economic and academic centre of the region. The location of Lublin itself may also influence the traffic that goes through it. Especially the proximity to the eastern border of Poland (incidentally, also the eastern boundary of the European Union) and the relatively small distance to the capital city create favourable conditions for the development of Lublin as a communication centre. According to the reports by the local press, every year up to four million people may visit the Main Bus Station in Lublin [Szlachetka 2017].

The internal part of the bus station and the neighbouring facilities are assumed as crucial for the travellers. The map featured, inter alia, public facilities such as shops, restaurants, vending machines et al. The station hall with ticket offices was also marked on the map, as well as the office of station management, a local market and the nearest streets with the public transport facilities. Their usability from the point of view of a user, understood as a traveller who does not know the topography of the area, was adopted as the selection criterion.

\section{Materials and methods}

\section{Digital base map as a source of spatial information}

The base map is a standardized, large-scale cartographic visualization. It contains information about the situation of geographical objects, elements of cadastral data, and the utility infrastructure [Act 1989, Bielecka and Izdebski 2014]. Local geodesy and cartography documentation centres, due to current law regulations, were required to create the base map in digital formal, based on information from databases, updated using geospatial data sources. In the case of this kind of data, the accuracy of the presentation is equal to the accuracy of measurement results with an error of less than a few centimetres. The vector record of the objects' geometry eliminates the influence of line thickness on the map reading correctness and, moreover, enables changing the scale or modifying the content using suitable software. Therefore, the digital base map may be used as a primary source for other cartographic elaborations [Bielecka and Izdebski 2014].

In practice, parts of a digital base map coexist with parts mapped by way of digitalization and vectorization of analogue maps, with a scale equal to 1:500 or less, which significantly decreases the accuracy of presented data and increases the likelihood of mistakes. Besides, not all the information on the map is completely up-to-date. Frequently, despite the expected correctness of the map, the materials obtained from land surveying and cartographic documentation centre require verification. In some cases, it is enough - in order to verify the data - to compare it with a current satellite or air images (e.g., orto- 
photomaps); however, sometimes a land measurement update is necessary. The assumed distortion depends mainly on the type and expected accuracy of the project.

\section{Research methods and technologies used}

The project process may be divided into two main stages. The first stage was an acquisition of the underlying data. Up-to-date data requirement and its accuracy guided the choice of data needed. The preliminary analysis was mainly performed with reference to a digital base map, obtained from Geodesy Department of the Lublin Municipal Authority in a vector DXF format. Missing data, consistent with the actual state, was obtained from the land survey. The surveying process included a situation measurement with a GNSS receiver, using the RTN method with reference to a statically measured point. The survey was performed with a Topcon HiPer V device, with the correction data from the TPI NETpro service. The additional, subsidiary information source, used in the comparison process, was the city geoportal of Lublin. All of the materials were compared and corrected, in order to achieve as high data reliability as possible.

The second stage consisted in graphic processing of the data from the database, using the following software: AutoCAD, EWMAPA, Inkscape, WinKalk, ArcMap, and ArcGIS Online. The final product is the result of the multistage process, combining several geoinformatics techniques and cartographic visualization methods.

\section{The process of creating the Interactive Map of the Main Bus Station in Lublin}

\section{Choosing the source of basic data}

One of the crucial processes of the initial stage of map creation (the conceptual stage), is adopting the range and themes for the visualization, and the choice a suitable data source [Medyńska-Gulij 2013]. In the course of designing the Interactive Map of the Main Bus Station in Lublin, the planned data sources were the elements of the base map. The choice was determined by accessibility and relatively high reliability of information - according to the assumption that the content of the base map should present accurate data, collected in the process of land surveying (either collected directly, or processed by digitalization). However, the accuracy of the data may be differentiated and, in some cases it needs to be verified and corrected, so that it can be used properly.

As an alternative data source, it is worth to mention the existing geoportals and other web maps (provided that the required objects have been digitalised). In the first case, there is a technical possibility of using the governmental or the municipal ortophotomap in order to vectorize the objects from a photo. However, this solution might cause some procedural inconveniences, associated with obtaining the required permits. An additional difficulty, in the case of the bus station map is that the lines of the curbs are covered by the shelter roofs. Using web maps usually also requires permissions from the administrators of respective services. An exception may be the OpenStreetMap 
service, used for sharing free geospatial data, although the content created by the users would have a varied degree of accuracy and reliability. Using this kind of source may be appropriate for designing less-detailed visualizations, for instance, for presenting a rough situation of streets and buildings.

\section{Collecting, selection, verifying and correcting the spatial data}

A continuous fragment of a vector base map was obtained in a DXF format, including fifteen evidential parcels, of the studied area and neighbourhood of the bus station. Due to the presence of unnecessary data layers (e.g., utility infrastructure), the materials were processed by making a selection in the AutoCAD software (Fig. 1), and then exported to the EWMAPA program. The choice was determined by the functionality of this kind of software, emerging from its compatibility with the regulations of law ruling the visualization of the geospatial data. As a result, a situation map was obtained, including the polygon layers of buildings, and a linear layer of curbs. For the generalization of the visualization process, presenting the polygon layers of the roads and pavements was aborted - the layout of the curbs was appropriate for the location of these objects.

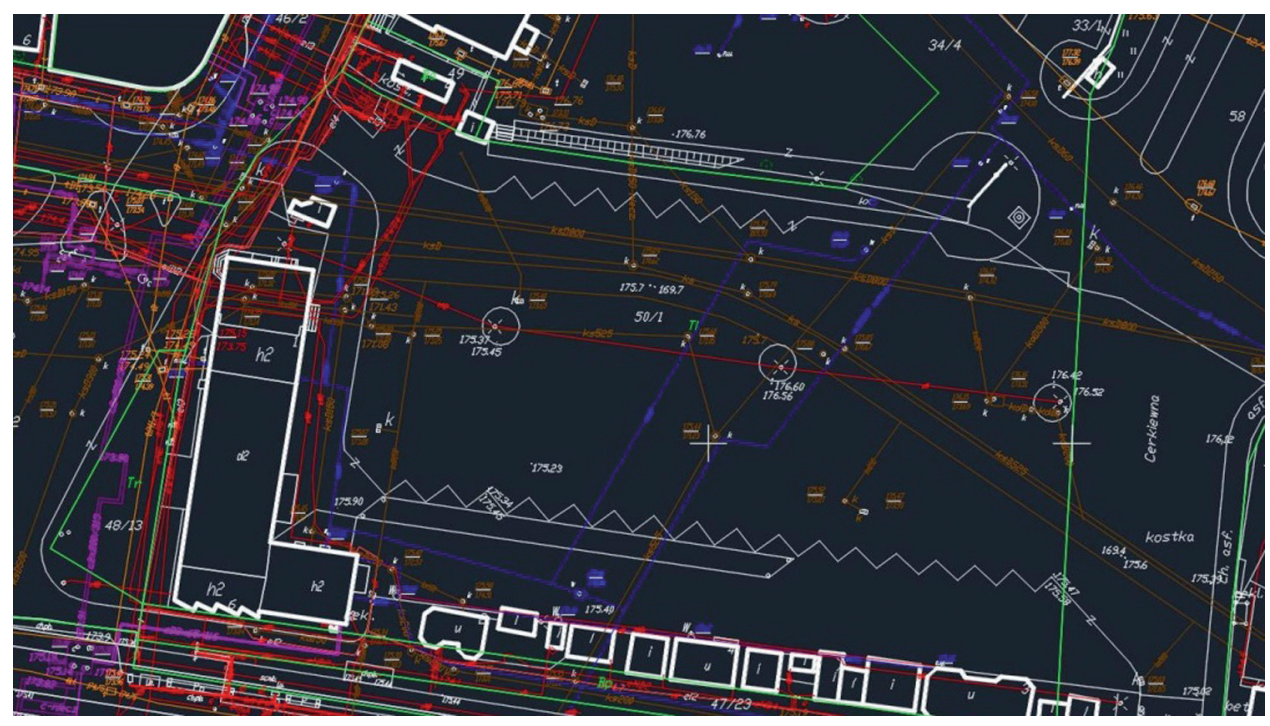

Source: digital base map maintained by the Geodesy Department of the Municipal Council of Lublin

Fig. 1. A fragment of the base map in DXF format depicted using the AutoCAD software

According to the expected reliability of the final representation, some control field observations were completed before the beginning of the map editing process. In spite of supposed correctness of the base map, there were significant discrepancies observed in the curbs system. This mistake would have a direct impact on the bus 
platforms layout, which would make the map incorrect and useless. Therefore, a decision to conduct further field measurements was taken. The works included measuring the essential elements of the bus station's interior and, additionally, some orientation points, such as the rough location of bus stands and front doors of the buildings.

From the available methods of measurements, satellite measurement with a GNSS receiver using an RTN mode was selected. The solution was recognized as optimal thanks to its ability of relatively speedy data registration and independence from traffic inconveniences. Accuracy down to a few centimetres, typical for this technique of measurement, was approved as sufficient for the present work. In the case of more accurate total station surveying, there was a significant problem of covering the visibility by pedestrians and vehicles. Moreover, when placed on the platform, the instrument would be exposed to vibrations, and the works might cause an inconvenience for people walking and drivers passing by.

During the surveying process, we have noticed one of the disadvantages of the techniques used: receiving the coordinates of some of the arranged points has turned out to be impossible because of an insufficient signal from the satellites, caused by the disruption of the satellite coverage by roofing and other structural elements of buildings. As a solution, pairs of subsidiary points were measured, and the missing coordinates were received from the lines' intersection equations. The calculations were carried out using the WinKalk software, and the result was exported as a text file.

The collected data, consisting of 329 points, was imported to the EWMAPA program and mapped according to the terms of the Regulation of the Ministry of Administration and Digitalization of 2 November 2015 as the Topographic Objects Database and the Base Map [Regulation 2015]. This has ensured the compatibility of the newly created map with the base map obtained from the Council. Further corrections focused on replacing the invalid fragment with the corrected version, while maintaining the continuity of the objects.

\section{Creating the interactive map}

Standardization of the processed layers of objects resulted in generating a vector map, with the intention of transforming it into the base for the interactive map. For this purpose, all of the topography elements of the studied area were converted into objects compatible with the cadastre and Topographic Objects Database standards. The default existing attribute tables were extended to include the category of precise definition of the function of each object. The finished objects were exported in the form of shapefiles - a format used by Esri software, including the ArcGIS Online service, to be used at a later stage for the purpose of creating and publishing the interactive map. An essential part of the shapefile was a PRJ file, defining the coordinate reference system of the map. The default shapefile, exported from EWMAPA, was incomplete because of the lack of the PRJ file and it needed to be supplemented by a downloaded component of a Poland CS2000 Zone 8 coordinate system, that is the official system for mapping the studied area in a large scale [GIS Support]. 
Data modified in the EWMAPA program would already enable the possibility of reading the land topography and displaying the information about the objects, based on the attribute tables. This effect would be labelled as an interactive map, provided that it was presented on a suitable platform understood as a device enabling changing the scale, moving the current visualization, choosing active layers and displaying database information about the mapped objects [Bąk et al. 2013]. However, this kind of visualization would not meet the requirements of practicality and intuitiveness of the map. A graphical modification was made in order to increase the usability of the display. The shapefiles were imported to the ArcMap program, a multifunctional solution for cartographic and geoinformatics works. The colour symbolization of the buildings was diversified according to their functions. This enabled displaying the categories of public utility sites in the map's key.

The last stage of the design process was implementing the compressed set of map layers into the ArcGIS Online web platform, intended both for creating and modifying the geospatial visualizations and hosting the maps on its server. Offered by the platform, the map editing facilities were used to upload interactive signatures, present numbers of bus platforms, public utility places, and other usable objects such as taxi rank and the nearest public transport. According to practical considerations, the picture signatures were regarded as the optimal solution, directly associating with symbolized objects and not requiring additional explanations in the map's key [Nieścioruk 2013]. The graphics of the signs was designed using free software for vector graphics - Inkscape. The primary assumption was their intuitiveness and visual attractiveness, having a significant influence on the map reception by the users [Wieczerzycki 2014]. The signatures (Fig. 2) were placed on the map and extended to include some information, which can be displayed by tapping each of the points and following diversified types of objects.

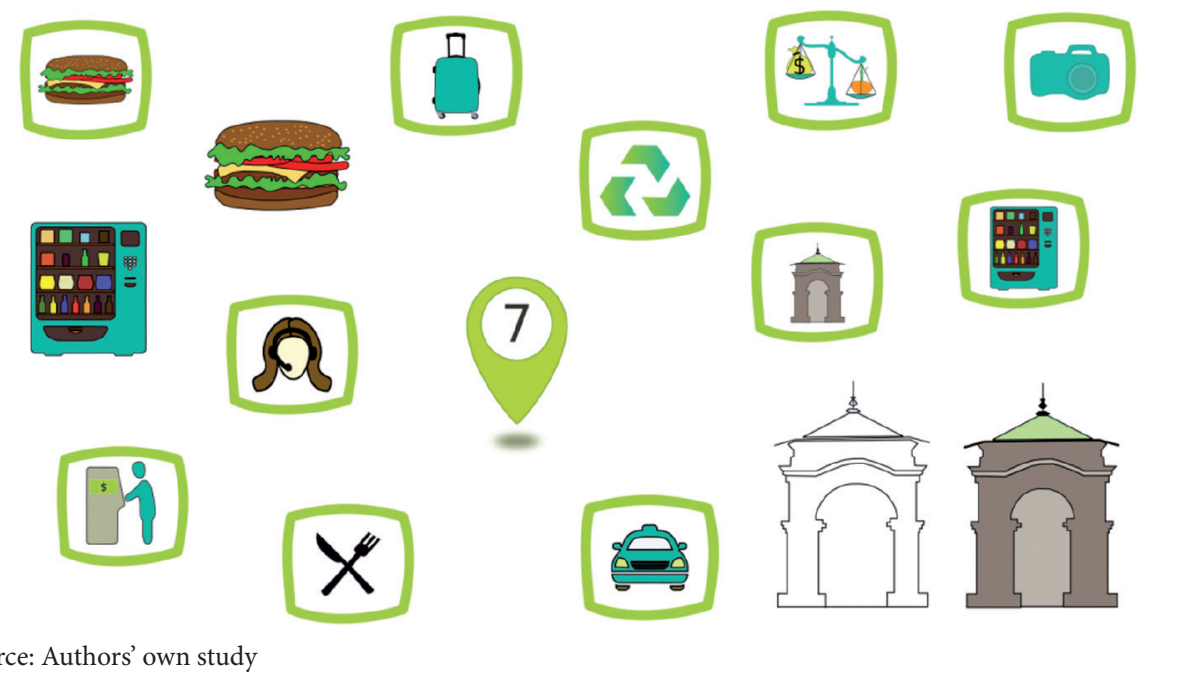

Fig. 2. An example of the signatures designed using Inkscape software 
As an example, the signatures of the bus platforms may show the destinations of the buses, the symbols of public utility places - their category, photograph and, whenever possible, address of the website. Furthermore, in the central location of the visualized area, an information button was placed, enabling the display of the map using instructions, and redirecting to a site containing an alphabetically ordered list of the available bus destinations with their respective platform numbers. We intentionally refrained from featuring the timetables, because of the inconvenient necessity of updating their content, whereas some comprehensive information service, including arranging a travel plan and ticket reservation, is available on the website of the Lubelskie Dworce SA company.

\section{Publishing the product for free use}

Designing a map with the ArcGIS Online service enables a possibility of noncommercial publishing the product on a server belonging to the owner and administrator of the system - Esri Inc. company. In the process of placing the map on the Internet, a shortened web address was received. The link enables every Internet user to display the map (Fig. 3). Additionally, due to arrangements made before the designing process, the map will be shared on the website of Lubelskie Dworce SA company. Moreover, dedicated stickers with the web address of the application, the QR code, and some short information about the content, will be placed in key locations of the bus station in order to help the travellers find out about the interactive map.

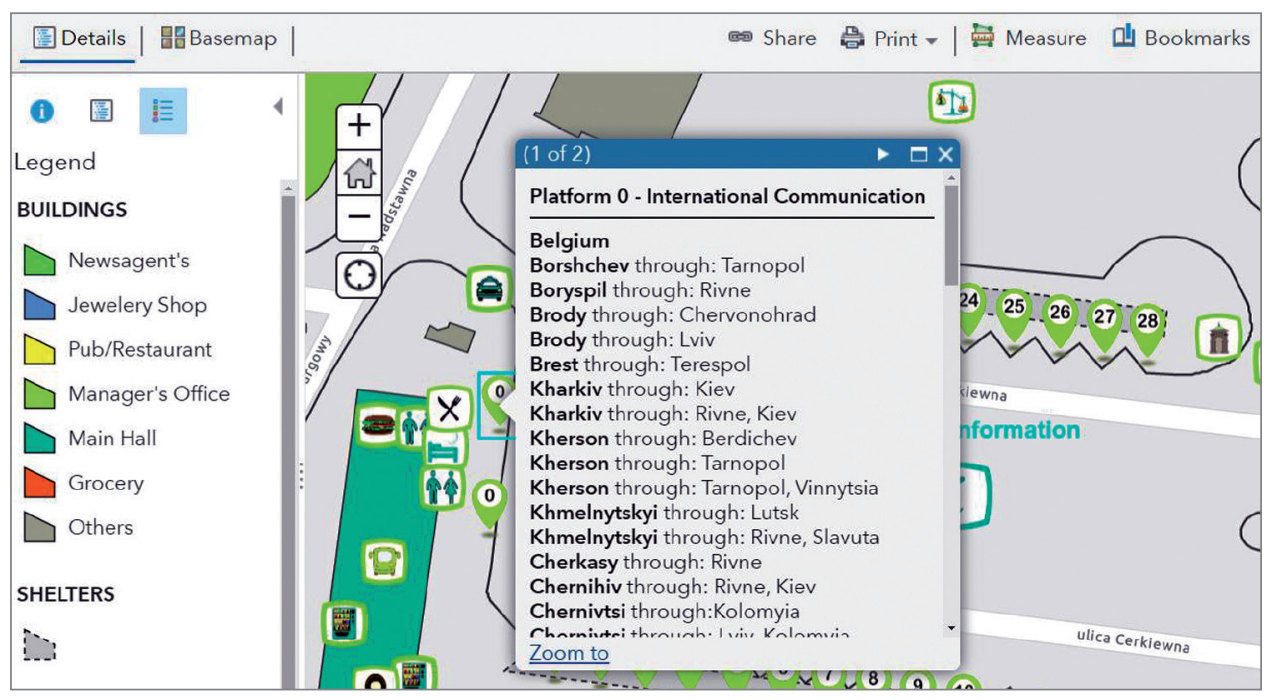

Source: Authors' own study

Fig. 3. A sample view of The Interactive Map of the Main Bus Station in Lublin 


\section{Conclusions}

As a result of the project, a complete spatial visualization of the bus station area was obtained, featuring in particular the objects that are useful for travellers, including bus platforms and the accompanying infrastructure. The graphics layers are extended to include a set of information about the presented objects and bus destinations, displayed on demand. The application is compatible with mobile devices and, therefore, it may be used as a comprehensive tool, assisting the travellers in moving through the station area. The intuitiveness of the visualization and the option of location tracking may be helpful in the orientation. The interactive features were designed to reduce the problem of displaying unnecessary information. Moreover, the application enables viewing the selected background map (e.g. the OpenStreetMap) beyond the station area, which improves the functionality of the tool significantly. The technology applied enables the map to be modified and overwritten with the same web address by the administrator each time when it needs an update.

Currently, the product is available on the Internet, at the following address: https:// www.arcg.is/vm4fm. Furthermore, the application works on the Lubelskie Dworce SA company's website, and in the near future, it will be also accessible by scanning the QR code from the stickers located throughout the bus station area.

Using the corrected and processed fragment of the base map, as expected, resulted in generating transparent terrain visualization. The chosen method of land surveying proved sufficiently accurate and the designing process may be recognized as successful.

The end product meets the requirements but it is not free of certain drawbacks. As an example, the platform we have used does not enable designing an interactive browser, related to the database. The existing browser is limited to the geographic data, what is significantly insufficient for this type of visualization.

The availability of various tools of geospatial data processing and technological methods of sharing that data opens many different options for modifying the application in order to upgrade its functionality. An essential goal to accomplish in the future is transferring the interactive map into a dedicated web service. This solution will enable unlimited extension of the project and its optimization in terms of communication with the users. One of the most crucial problems likely to be solved in this way is creating an automatized browser of connections and useful places, which can help the user in travel planning.

\section{References}

Act 1989. Ustawa z dnia 17 maja 1989 r. - Prawo geodezyjne i kartograficzne. Dz. U. z 1989 r. Nr 30, poz. 163 z późn. zm.

Aletà N.B., Alonso C.M., Arce Ruiz R.M. 2017. Smart Mobility and Smart Environment in the Spanish Cities. Transportation Research Procedia, 24, 163-170.

Bąk G., Chromik B., Mika M., Sałata T. 2013. Metodyka utworzenia interaktywnej mapy fragmentu szlaków górskich Beskidu Śląskiego. Infrastruktura i Ekologia Terenów Wiejskich (Infrastructure and Technology of Rural Areas), 2 (II), 87-97. 
Bielecka E., Izdebski W. 2014. Od danych do informacji. Teoretyczne i praktyczne aspekty funkcjonowania mapy zasadniczej. Roczniki Geomatyki, XII, 2(64), 175-184.

Gagliardi D., Schina L., Sarcinella M.L., Mangialardi G., Niglia F., Corallo A. 2017. Information and communication technologies and public participation: Interactive maps and value added for citizens. Government Information Quarterly, 34, 1, 153-166.

Gaździcki J. 2012. Trendy rozwojowe w dziedzinie informacji geoprzestrzennej. Roczniki Geomatyki, X, 3(53), 7-16.

GIS Support. https://gis-support.pl/uklady-wspolrzednych-w-praktyce/ (accessed: 13.06.2019)

Król K., Prus B. 2016. The comparative analysis of selected interactive data presentation techniques on the example of the land use structure in the commune of Tomice. Polish Cartographical Review, 48(3), 115-127.

Król K., Prus B. 2017. Comparison of selected methods of interactive geovisualization on the basis of a monuments. Geomatics, Landmanagement and Landscape, 4, 55-66.

Kuwałek R. 2003. Terra incognita. Ulica Szeroka w Lublinie. Scriptores: Pamięć, Miejsce, Obecność, 2(28), 9-28.

Macioch A., Malmon G. 2010. Funkcje interaktywne współczesnych map elektronicznych. Polski Przegląd Kartograficzny, 44, 4, 331-353.

Medyńska-Gulij B. 2013. Kartografia i geowizualizacja. Wydawnictwo Naukowe PWN, Warszawa.

Nieścioruk K. 2013. Kartograficzny obraz map mentalnych przestrzeni miejskiej i jego prezentacja oraz analiza z zastosowaniem narzędzi systemów informacji geograficznej. Geodesia et Descriptio Terrarum, 12(4), 27-40.

Pochwatka P., Litwin U., Teterycz T., Bitner A. 2017. Cartographic Visualization in the Real Estate Market Investigation with the Use of GIS Tools. 2017 Baltic Geodetic Congress (Geomatics), 105-109.

Regulation 2015. Rozporządzenie Ministra Administracji i Cyfryzacji z dnia 2 listopada 2015 r. w sprawie bazy danych obiektów topograficznych oraz mapy zasadniczej. Dz. U. z 2015 r., poz. 2028.

Smith D.A. 2016. Online interactive thematic mapping: Applications and techniques for socioeconomic research. Computers, Environment and Urban Systems, 57, 106-117.

Szlachetka M. 2017. Dworzec Główny PKS w Lublinie świętuje urodziny. https://kurierlubelski. $\mathrm{pl} /$ dworzec-pks-w-lublinie-swietuje-urodziny/ar/12518656 (accessed: 25.03.2019).

Wieczerzycki M. 2014. Wymiary nowych mediów a reinterpretacja pojęcia konsumenta w teoriach marketingowych. Marketing i Rynek, 21(10), 11-18.

Mgr inż. Patrycja Pochwatka

Uniwersytet Przyrodniczy w Lublinie

Katedra Inżynierii Środowiska i Geodezji

20-069 Lublin, ul. Króla Stanisława Leszczyńskiego 7

e-mail: patrycja.pochwatka@up.lublin.pl

ORCID: 0000-0001-7108-4078

Klaudia Mazur

Uniwersytet Przyrodniczy w Lublinie

Geodezyjne Koło Naukowe „Equator"

20-950 Lublin, ul. Akademicka 13

e-mail: klaudia.mazur7@o2.pl 
Michał Maciąg

Uniwersytet Przyrodniczy w Lublinie

Geodezyjne Koło Naukowe „Equator"

20-950 Lublin, ul. Akademicka 13

e-mail:mim97@outlook.com 